ISSN 2411-4758 (Print) 2518-1602 (Online)

Native word in ethnocultural dimension, Drohobych, Posvit, 2021, pp. 197-204.

DOI: https://doi.org/10.24919/2411-4758.2021.213929

УДК 373.3.016:003-028.31

\title{
РОЛЬ УЧИТЕЛЯ В НАВЧАННІ УЧНІВ КАЛІГРАФІЧНОГО ПИСЬМА
}

\section{Світлана ЛУЦІВ,}

кандидат педагогічних наук, дочент кафедри філологічних дисичиплін та методики їх викладання у початковій школі, Дрогобицький державний педагогічний університет імені Івана Франка (Украӥна, Дрогобич)lutsiw@ukr.net

ORCID: http://orcid.org/0000-0003-3219-7779

Research ID: I-5194-2018 http://www.researcherid.com/rid/I-5194-2018

Статтю подано до редколегіï / The article is submitted to the editorial board:11.10.2020.

Статтю опубліковано / The article is published: 22.02.2021.

У статті з'ясовано та доведено важливість роботи вчителя під час формування каліграфічного письма в учнів початкової школи; доведено, щуо у початковій школі навчання з каліграфї проводиться на кожному урочі, зміст занять $з$ каліграфії визначено тематикою уроку з украӥнської мови; обтрунтовано, щуо на уроках украӥнської мови учні початкової школи вправляються у розвитку окоміру, написанні букв за порядком ускладнення їх; визначено, що допомога вчителя має бути своєчасною і постійною під час формування каліграфічних навичок молодших школярів; педагог має привернути увагу учня до того, щчо йому вдається важче, мотивувати до самоконтролю, підібрати вправи, які формували навички письма.

Ключові слова: каліграфія; каліграфічне письмо; каліграфічна навичка; буква; письмо.

\section{THE ROLE OF THE TEACHER IN TEACHING STUDENTS OF CALLIGRAPHIC WRITING}

\section{Svitlana LUTSIW,}

Ph.D. in Pedagogical, docent, Department of philological sciences and techniques of teaching in elementary school, Drohobych Ivan Franko State Pedagogical University (Ukraine,Drohobych) lutsiw@ukr.net 
Modern primary education aims to ensure the comprehensive development of students through education and training. These tasks are based on universal values and such principles. The quality and effectiveness of primary school education depends on the activities of the teacher, during which a high level of learning in any subject must be ensured. The primary school teacher must have a thorough knowledge of all primary school subjects, including calligraphy, as required by the specifics of his work.

The formation of calligraphic writing in primary school students is a complex process. Students must master technical, graphic, and spelling skills. Younger students who master these skills will have good handwriting and literacy. These skill groups can only be formed by an elementary school teacher. Therefore, the question of the role of the teacher in the formation of calligraphic writing in primary school students is very important.

The purpose of the article is to find out and prove the importance of the teacher's work in the formation of calligraphic writing in primary school students.

In elementary school, calligraphy is taught in every lesson. The content of calligraphy classes is determined by the theme of the Ukrainian language lesson. In such classes, students practice the development of eye movement, writing letters in the order of their complication. Students learn to write all the lowercase letters of the alphabet and combine them into words in groups. Gradually, students learn to write words, sentences, and coherent texts. An important place is given to exercises for writing individual syllables and difficult for students letter combinations, writing to the beat, under the dictation of the teacher. All this acquires special significance for the gradual mastery of calligraphic writing by students.

The success of students in mastering calligraphic writing depends on the teacher's preparation for work, on his own skills of calligraphic writing. If the teacher does not violate the rules of writing, hygienic requirements for him, will be a role model for students, the teacher's manners will be inherited by his students.

Key words: calligraphy; calligraphic writing; calligraphic skill; letter, writing.

Постановка проблеми. Сучасна початкова освіта має на меті забезпечити всебічний розвиток школярів шляхом виховання і навчання. Ці завдання грунтуються на загальнолюдських цінностях i принципах. Якість та ефективність навчання учнів початкової школи залежать від діяльності вчителя, який прагне дати учням глибокі знання з усіх предметів початкової школи. Учитель початкової школи має володіти грунтовними знаннями з усіх предметів початкової школи, зокрема $з$ каліграфії, оскільки цього вимагає специфіка його роботи.

Аналіз досліджень. Формування каліграфічного письма в учнів початкової школи - складний процес. Учні мають оволодіти технічними, графічним та орфографічними навичками. Молодші школярі, які оволодіють цими навичками, матимуть гарний почерк та грамотне письмо. Ці 
групи навичок може сформувати тільки вчитель початкової школи. Тож питання про роль вчителя під час формування каліграфічного письма в учнів початкової школи є дуже важливим. До проблеми формування каліграфічного письма зверталися як психологи, так і фізіологи та педагоги (Ш. Амонашвілі, М. Вашуленко, Л. Виготський, М. Пентилюк, О. Скрипченко).

Мета статті. 3'ясувати та довести роль вчителя під час формування каліграфічного письма у молодших школярів.

Виклад основного матеріалу. У початковій школі навчання каліграфії проводиться на кожному уроці. Характер вправ із каліграфії визначається тематикою уроку з української мови. Під час їх виконання учні розвивають окомір, вчаться писати букви за порядком їх ускладнення Перед учнями стоїть завдання навчитися писати букви алфавіту (рядкові), поєднувати їх між собою, далі - писати різноманітні слова, доступні речення й зв'язні висловлення.

Формування каліграфічних навичок залежить від того, наскільки доцільно з педагогічного та психологічного поглядів добиратимуться вправи $з$ письма. Важлива роль належить тим, що спрямовані на написання складів та важких для молодших школярів сполучень букв. До них можна зарахувати письмо під такт та під диктовку вчителя.

Провідні методисти зазначають, що правильне й коментоване письмо вчителя на дошці учні засвоюють значно краще. Тож можна стверджувати, що коментування має важливе значення під час засвоєння учнями каліграфічного письма.

Якщо учні вивчали написання малої букви, то необхідно дібрати для вправляння такі слова, де б ця буква була в різних позиціях. Важливо, щоб учні засвоїли різні способи поєднання букв. Учитель має застерегти учнів від помилок, які можуть негативно впливати на якість каліграфічного письма.

Учні під керівництвом учителя мають засвоїти, що висота рядкових букв має бути не більше половини висоти робочого рядка, а великі букви треба писати трохи нижче верхньої лінії; висота та ширина малих і великих букв мають бути однаковими; усі букви пишуть під нахилом, елементи букв мають бути паралельними; букви, склади та слова треба старатися писати безвідривно.

Під час формування каліграфічного письма молодший школяр має чітко уявляти фору букв. Учні вчаться писати букви правильної форми й одночасно звертати уваги на зміст письма. Це досягається шляхом вироблення в учнів точних і сталих навичок. 
Оскільки каліграфічне письмо починаємо формувати уже з першого класу, то важливо виробити в першокласників ті рухи пальців кисті руки, які задіяні під час швидкого письма. Це дасть змогу запобігти переучуванню дітей. Для формування та вдосконалення каліграфічного письма учнів початкової школи можна запропонувати такі завдання: написання елементів букв, написання алфавіту букв з одночасним їх поєднанням, запис слів та складів під такт, списування текстів (Луців, 2018, c. 193).

Так, для написання алфавіту малих букв з одночасним поєднанням пропонується учням списати його з друкованої основи. Учитель може вивісити плакат з друкованим алфавітом, а учні, дивлячись на нього, мають записати алфавіт прописними буквами безвідривно.

Письмо - складний психофізіологічний процес, у якому важливий і рух очей, i рух руки, і мисленнєві операції учня. Для того, щоб каліграфічні навички були стійкими й міцними, важлива взаємодія моторно-рухових навичок правої чи лівої руки, кисті, пальців. Тільки систематична, уважна й послідовна робота, спрямована на вироблення та збереження правильного й каліграфічного письма дасть позитивні результати (Воронова, 2006, с. 23).

Відомо, що будь-яка діяльність дитини не проходить самостійно, а охоплює їі всю, тож під час формування навичок письма важливого значення набуває загальний розвиток учня, його зацікавленість та свідоме ставлення до виконуваних завдань.

Основні труднощі під час навчання письма полягають у складності психофізіологічної структури графічної навички, бо процес письма складний психологічний акт. Перед молодшим школярем постають такі завдання: технічні, графічні та орфографічні. Кожне з цих завдань має свої особливості. Для правильного їх виконання молодші школярі мають проробити важку аналітико-синтатичну роботу, під час якої важливе значення має допомога вчителя.

Контроль вчителя має бути своєчасним та постійним. Важливо, щоб педагог зосереджував увагу учня на тому, що він гірше засвоює (Савченко, 1993, с. 23).

Учитель має контролювати формування графічних навичок в учнів на кожному уроці. Графічні навички в освітньому процесі посідають надзвичайно вагоме місце, адже слугують основою для вивчення кожного $з$ предметів початкової школи. Важливими факторами успішного навчання учнів початкової школи є чіткість та темп письма.

На початку кожного уроку української мови класовод має писати на класній дошці виучувані букви та окремі їх сполучення й коментувати 
те, що написали учні, звертати особливу увагу школярів на структуру та назву кожного елемента букви.

Важливого значення для успішного формування каліграфічного письма набуває кваліфіковане, систематичне керівництво й контроль за виконанням учнями практичних самостійних завдань. Учитель може систематично аналізувати та демонструвати кращі зразки письма у зошитах. А ще можна пропонувати школярам самостійно аналізувати власні роботи. Провідні методисти вважають, що для формування міцних і сталих навичок каліграфічного письма вагомого значення набувають зразки письма вчителя у зошитах. Правильне й коментоване письмо вчителя на класній дошці учні засвоюють значно краще. Тож можна стверджувати, що коментування відіграє важливу роль у засвоєнні учнями каліграфічного письма.

Майбутні вчителі початкових класів мають можливість прослухати курс «Каліграфія». Метою вивчення цього курсу є: ознайомити здобувачів другого (магістерського) рівня вищої освіти 3 методичними прийомами і способами навчання каліграфії, з закономірностями розвитку техніки письма, з методикою виявлення порушень писемного мовлення; формувати уміння каліграфічного письма в майбутніх учителів початкової школи; навчити здобувачів методично правильно пояснювати написання букв, їх елементів, основних з’єднань учням початкової школи.

Програма навчальної дисципліни складається 3 таких розділів:

Теоретичні основи навчання каліграфічного письма. Під час вивчення цього розділу студенти ознайомлюються з такими темами: Каліграфія як наука. Основні етапи вивчення каліграфії. Зв'язок каліграфії 3 іншими навчальними дисциплінами. Завдання навчання каліграфічного письма. Умови навчання каліграфічного письма. Методи навчання каліграфічного письма: лінійний, тактовий, аналітико-синтетичний, генетичний, копіювальний. Методичні прийоми навчання чистописання в початковій школі. Психолого-педагогічні основи формування графічної навички в учнів початкової школи. Організаційні та гігієнічні умови навчання письма. Характеристика рукописного шрифту для навчання письма шестирічних першокласників.

Формування навичок каліграфічного письма. Під час вивчення цього розділу студенти ознайомлюються 3 такими темами: Методика написання елементів букв, букв та їх з’єднань. Підготовчі вправи з письма в добуквений період навчання грамоти. Структура уроку письма добуквеного періоду.

Поділ малих букв українського алфавіту на групи. Письмо в буквений період навчання грамоти. Структура уроку письма буквеного періоду. Ме- 
тодика написання малих букв I-VIII груп. Складні з’єднання малих букв. Поділ великих букв українського алфавіту на групи. Методика пояснення написання великих букв I-VIII груп. Складні з'єднання великих букв.

Норми каліграфічного письма та необхідність їх дотримання. Шляхи усунення неточностей і помилок під час написання тієї чи тієї букви. Списування з друкованого й рукописного текстів.

Формування та вдосконалення навичок письма в післябуквений період навчання грамоти. Структура уроку письма післябуквеного періоду. Каліграфічне написання арабських цифр.

Удосконалення навичок каліграфічного письма в учнів 2-4 класів. Письмо малих і великих букв за групами в зошиті в одну лінію. Каліграфічні хвилинки на уроках української мови в початкових класах, вимоги до їх проведення.

Методика запису слів. Методика виявлення порушень писемного мовлення. Сутність компетентнісного підходу та особливості його реалізації при корекції порушень писемного мовлення.

Шляхи подолання неточностей і помилок під час написання учнями букв. Система вправ для розвитку руки дитини. Нетрадиційні методики підготовки руки дитини до письма. Навчання письма ліворуких дітей. Каліграфія і розвиток зв'язного мовлення.

Навчальна дисципліна сприяє формуванню у студентів низки компетентностей, серед яких можна виділити:

а) загальні компетентності:

- діяти соціально, відповідально і свідомо;

- генерувати нові ідеї (креативність);

- бути критичними і самокритичними;

б) фахові компетентності:

- організовувати діяльність початкової школи;

- здійснювати нормативне та правове регулювання діяльності початкової школи, керуючись законодавчими документами;

- бути обізнаними на рівні основ фундаментальних наук та сучасних досягнень педагогіки та фахових методик початкової школи;

- бути здатними до самоосвіти та самовдосконалення.

Вивчення дисципліни спрямовується на формування таких програмних результатів навчання:

- критично осмислювати концептуальні засади, цілі, завдання, принципи функціонування початкової освіти в Україні;

- впроваджувати інформаційні та комунікаційні технології й генерувати нові ідеї в організаціїю освітнього процесу закладів початкової освіти різного типу; 
- здійснювати психолого-педагогічне керівництво індивідуальним розвитком особистості дитини молодшого шкільного віку;

- знати й використовувати в практичній діяльності законодавчу базу початкової освіти;

- володіти уміннями й навичками аналізу, прогнозування, планування, організації освітнього процесу в початковій школі з урахуванням принципів дитиноцентризму, здоров'язбереження, інклюзії, розвивального навчання, особистісно-орієнтованого підходу, суб' єкт-суб'єктної взаємодії, компетентнісного підходу;

- впроваджувати в освітній процес сучасні освітні технології та інноваційні методики навчання, виховання та розвитку дитини молодшого шкільного віку;

- застосовувати в професійній діяльності сучасні дидактичні та методичні засади викладання психолого-педагогічних дисциплін і обирати відповідні технології та методики.

У результаті вивчення навчальної дисципліни студенти мають:

I. Знати:

- методи, прийоми, способи навчання каліграфічного письма;

- умови навчання каліграфічного письма;

- письмове приладдя;

- графічну сітку зошита;

- основні елементи букв;

- додаткові елементи букв;

- складні з'єднання малих букв;

- складні з'єднання великих букв;

- методику запису складів;

- методику запису слів;

- методику запису речень.

\section{II. Уміти:}

- орієнтуватися в лініях зошитів із графічними сітками;

- каліграфічно правильно зображувати рукописні рядкові і великі букви українського алфавіту;

- правильно поєднувати букви у процесі написання слів;

- коментувати написання букви та поєднання іії з іншими буквами;

- розробляти каліграфічні хвилинки для вдосконалення графічної навички письма в учнів 2-4 класів;

- володіти методами й прийомами каліграфічного письма, гігієнічними вимогами до нього;

- володіти прийомами розкриття термінів під час вивчення матеріалу з дисципліни; 
- працювати з ліворукими учнями;

- $\quad$ аналізувати причини індивідуальних відхилень від правильного письма та знати способи усунення їх.

Висновки та перспективи подальшого дослідження. Отже, успіх у засвоєнні учнями каліграфічного письма залежить значною мірою від підготовки вчителя до роботи, від його власних навиків каліграфічного письма. Якщо педагог не порушуватиме правил письма, гігієнічних вимог до нього, буде взірцем для учнів, то манери вчителя унаслідують його вихованці.

\section{СПИСОК ЛІТЕРАТУРИ}

Воронова, Н. (2006). Підготовка руки дитини до письма. Матеріали Всеукраӥнської науково-практичної конферениії «Підвищення ефективності логопедичної роботи в умовах здійснення дошкільної та початкової освіти». Херсон: Айлант, $19-23$.

Луців, С. (2018). Забезпечення наступності у підготовці руки до письма дітей старшого дошкільного віку та учнів першого класу. Рідне слово в етнокультурному вимірі: зб. наук. праць. Дрогобич: Посвіт, $191-199$.

Савченко, О. (1993). Урок у початкових класах: Навчально-методичний посібник. Київ. Освіта.

\section{REFERENCES}

Voronova, N. (2006). Pidhotovka ruky dytyny do pysma [Preparing a child's hand for writing] Materialy Vseukrayinskoyi naukovo-praktychnoyi konferentsiyi "Pidvyshchennya efektyvnosti lohopedychnoyi roboty $v$ umovakh zdiysnennya doshkilnoyi ta pochatkovoyi osvity». Kherson: Aylant, 19-23. [in Ukrainian].

Lutsiv, S. (2018). Zabezpechennya nastupnosti u pidhotovtsi ruky do pysma ditey starshoho doshkilnoho viku ta uchniv pershoho klasu [Ensuring continuity in the preparation of the hand for writing of older preschool children and first graders] Ridne slovo $v$ etnokulturnomu vymiri: $z b$. nauk. prats - Native word in the ethnocultural dimension: Coll. Sciense. Drohobych: Posvit, 191 - 199. [in Ukrainian].

Savchenko, O. (1993). Urok u pochatkovykh klasakh: Navchalno-metodychnyy posibnyk [Lesson in primary school: Textbook] Kyiv: Osvita. [in Ukrainian]. 